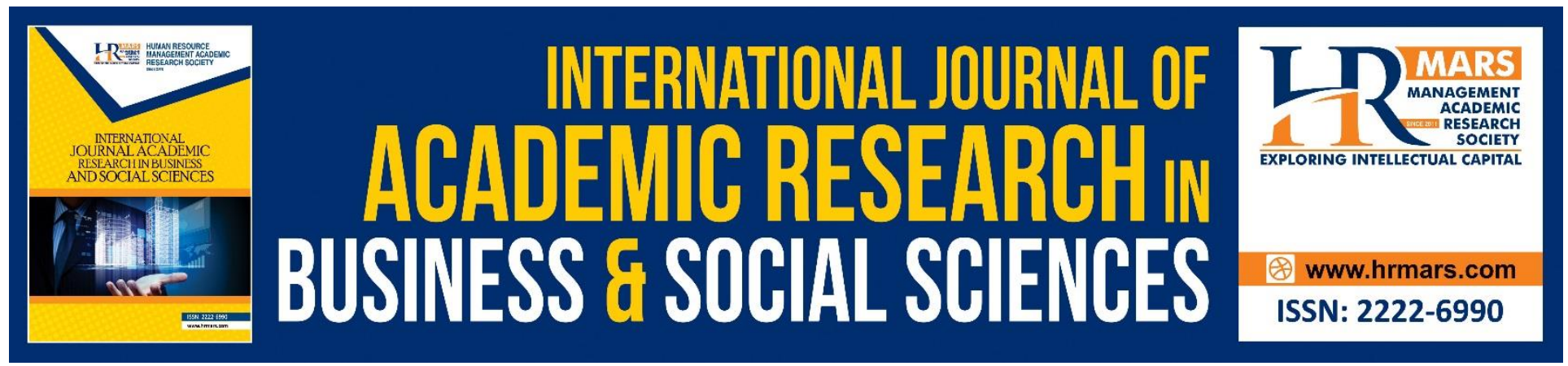

\title{
Teachers' Concern towards Applying Computational Thinking Skills in Teaching and Learning
}

\section{Susan Senin \& Nurfaradilla Mohamad Nasri}

To Link this Article: http://dx.doi.org/10.6007/IJARBSS/v9-i1/5398

DOI: $\quad 10.6007 /$ IJARBSS/v9-i1/5398

Received: 04 Jan 2019, Revised: 21 Jan 2019, Accepted: 30 Jan 2019

Published Online: 10 Feb 2019

In-Text Citation: (Senin \& Nasri, 2019)

To Cite this Article: Senin, S., \& Nasri, N. M. (2019). Teachers' Concern towards Applying Computational Thinking Skills in Teaching and Learning. International Journal of Academic Research in Business and Social Sciences, 9(1), 296-310.

\section{Copyright: (c) 2019 The Author(s)}

Published by Human Resource Management Academic Research Society (www.hrmars.com)

This article is published under the Creative Commons Attribution (CC BY 4.0) license. Anyone may reproduce, distribute, translate and create derivative works of this article (for both commercial and non-commercial purposes), subject to full attribution to the original publication and authors. The full terms of this license may be seen

at: http://creativecommons.org/licences/by/4.0/legalcode

Vol. 9, No. 1, 2019, Pg. 296 - 310

http://hrmars.com/index.php/pages/detail/IJARBSS

JOURNAL HOMEPAGE

Full Terms \& Conditions of access and use can be found at http://hrmars.com/index.php/pages/detail/publication-ethics 


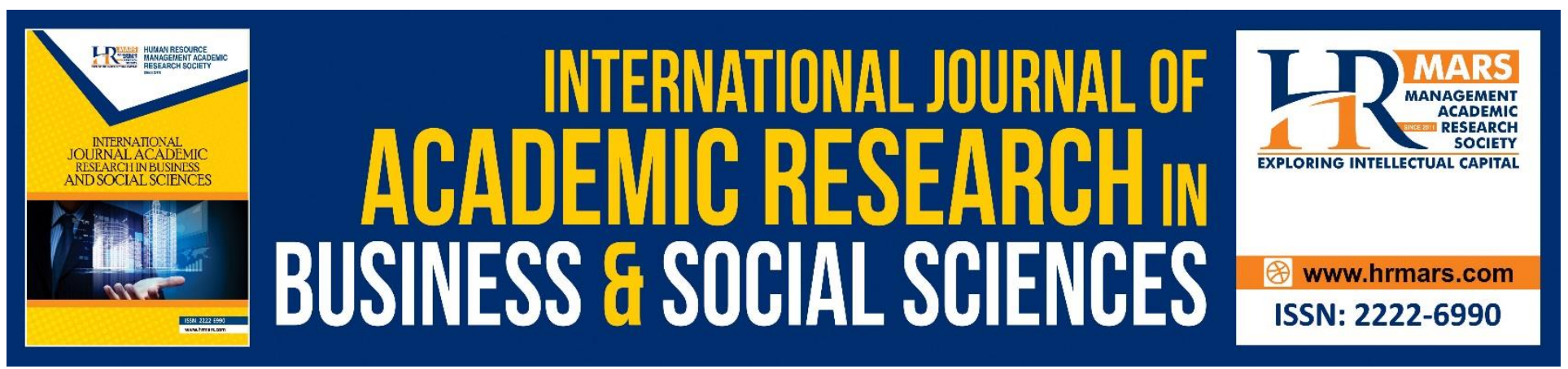

\title{
Teachers' Concern towards Applying Computational Thinking Skills in Teaching and Learning
}

\author{
Susan Senin \& Nurfaradilla Mohamad Nasri \\ Faculty of Education, Universiti Kebangsaan Malaysia (UKM), 43600 UKM Bangi, Selangor \\ Malaysia \\ Email: susan_senin@yahoo.com,nurfaradilla@ukm.edu.my
}

\begin{abstract}
The purpose of this study was to examine the teachers' concern towards applying computational thinking skills in their teaching and learning. This study used Concerns-Based Adoption Model (CBAM) to identify the Stages of Concern $(\mathrm{SoC})$ of the respondents. The questionnaires used were 35 items that were measured using a Likert scale of 7 points. Questionnaires were distributed to all the teachers in a district in Sarawak, Malaysia. A total of 564 responds were collected in this study. The findings indicated that the respondents were at the Unconcerned Stage (Stage 0) with highest percentile score of $94 \%$, followed by Informational Stage (Stage 1) and Management Stage (Stage 3). The findings also indicated that the respondents showed minimal concern but are interested and need more information on how to apply computational thinking skills in teaching and learning. The findings of this study are expected to assist the concern and the ministry to improve the delivery of information concerning computational thinking skills in teaching and learning to the teachers.
\end{abstract}

Keywords: stages of concern, computational thinking, innovation, CBAM, teaching and learning

\section{INTRODUCTION}

Computational thinking (CT) skills have been introduced together with information and communication technology (ICT) skills as one of the steps to improve the existing curriculum in schools in Malaysia. The change to the existing curriculum through the integration of CT skills is based on the current education transformation in line with the global demands (Ministry of Education [MOE] 2016). CT skills have been considered as one of the steps to develop students' ability to solve problems. Through CT skills, students are trained to think rationally and systematically to solve problems using basic principles of computer science. According to Wing (2017), CT is the thought processes involved in formulating a problem and presenting its solution in a method that a computer, human or machine can accomplish. CT describes the practice of thinking in solving problems through computational solutions that include computations, algorithmic thinking, computerization, resolution, deletion and simplification (Angeli et al. 2016; Bocconi et al. 2016). CT can also be 
described as a process of thinking where solutions to problems can be designed and assessed by data processing techniques (Mohaghegh \& McCauley 2016).

A variety of definitions of CT have been raised by researchers proves that CT can be applied on a large range across many disciplines in addition to in computer science and information science where CT can be used to solve complex problems (Voogt et al. 2015; Yadav et al. 2014). Although there is some dissimilarity related to the definition of CT, most researchers agree that CT is a necessary skill and should be mastered in the $21^{\text {st }}$ century (Mohaghegh \& McCauley 2016). Thus, recognizing the importance and benefits of $\mathrm{CT}$, it is the duty of teachers to apply CT skills in their teaching and learning activities.

The initiative to include the concept of CT skills in the education system has been highly stressed in some countries. In fact, CT has been considered as $21^{\text {st }}$ century literacy by concerned parties in computer science and education (Mohaghegh \& McCauley 2016). The biggest global movement of CT and programming is the Hour of Code campaign which participated by 15 million students worldwide during the Computer Science Education Week 2014 (Israel et al. 2014). Hour of Code is an international movement initiated by code.org. The Hour of Code awareness campaign was held throughout Malaysia in October 2017 to November 2017 involving 745 schools and 80037 pupils (MOE 2018) to provide early exposure and increase student's knowledge of coding skills, programming and computer science (MOE 2017). In addition, this campaign has been awarded the "most coding activity" by the Malaysia Book of Records (MBOR).

\section{Concern-Based Adoption Model (CBAM)}

A teacher's concern about innovation is varied depending on the level of knowledge, experience and service of the teacher (George, Hall \& Stiegelbauer 2013). A person who never uses the innovation will experience different stages of concern because an innovation needs new knowledge and skills to be learned. To examine the stages of concern over the application of computational thinking skills in teaching and learning, this study uses the Concern-Based Adoption Model (CBAM). CBAM has been recognized by various researchers in which it facilitates us to understand and to classify the stages of teacher's concern for the change (Holloway 2003) from the beginning of the innovation in the education system (Matar 2015) in order to improve the quality of education (Roselita et al. 2017). CBAM is a particularly developed model for assessing the implementation of innovative curriculum or educational programs (Sharifah et al. 2012) and has been applied in numerous studies involving various educational innovations (Wang 2014). This statement is supported by Matar (2015) which states that CBAM is an instrument for screening, calculating, defining, and explaining the progress of change experienced by the teachers when an educational innovation is introduced and implemented.

CBAM classified concerns over the seven stages of concern namely Stage 0 (Unconcerned), Stage 1 (Informational), Stage 2 (Personal), Stage 3 (Management), Stage 4 (Consequence), Stage 5 (Collaboration) and Stage 6 (Refocusing). The stages of concern on "Unconcerned" and "Informational" are the stages of Self-Concern, "Management" is the Task-Concern and "Collaboration" and "Refocusing" are the Impact-Concern. Every individual involved in a new innovation must move from the Self-Concern to the Task-Concern, and then to the Impact-Concern to bring about the success of innovation (Sharifah et al. 2012). The seven stages of concern for innovation are as in the following table. 
INTERNATIONAL JOURNAL OF ACADEMIC RESEARCH IN BUSINESS AND SOCIAL SCIENCES Vol. 9, No. 1, Jan, 2019, E-ISSN: 2222-6990 (C) 2019 HRMARS

Stages of Concern About an Innovation. Source: Adaptation from George, Hall and Stiegelbauer (2013) page 8.

6 Refocusing their teaching and learning as well as the opportunity of making or replacing them with more effective alternatives.

\begin{tabular}{ll} 
Impact 5 Collaboration & $\begin{array}{l}\text { Teachers focus on collaboration with other teachers in applying CT } \\
\text { skills in their teaching and learning. }\end{array}$ \\
\cline { 2 - 2 } 4 Consequence & $\begin{array}{l}\text { Teachers focus on the impact of applying CT skills in teaching and } \\
\text { learning on students and changes needed to improve student } \\
\text { outcomes. }\end{array}$
\end{tabular}

Teachers focus on processes and tasks of applying CT skills in teaching

Task 3 Management and learning and the best use of information and resources. Preferred issues are more relevant to efficiency, management, preparation and scheduling.

Teachers have anxieties about their role and ability in applying CT skills in teaching and learning. Teachers are concerned about the impact of 2 Personal applying CT skills in teaching and learning on themselves and their existing commitments including the implications for themselves and colleagues.

Self Teachers are well aware of applying CT skills in their teaching and learning and are interested in learning more about the innovations.

1 Informationa Teachers are less concerned about or less involved in applying CT skills 0 Unconcerned in teaching and learning.

CBAM has three dimensions of diagnostic components namely Stages of Concern, Levels of Use and Innovation Configurations (Loucks 1983). However, this study will only review the stages of concern using the Stages of Concern dimension. This dimension is a framework for measuring the implementation of changes that occur in schools among teachers. By identifying the stages of concern, researchers may identify the future needs to help the teachers to be able to apply CT skills in their teaching and learning.

\section{PROBLEM STATEMENT}

Understanding the stages of teachers' concern towards applying CT skills in their teaching routines is necessary to make sure that it is successfully implemented. However, examining the stages of concern for an innovation in education is not easy (Hall et al. 1973). A teacher may apply the CT skills in his teaching and learning activities while his colleagues may choose not to apply. There is a level of progress in applying CT skills in education system that every teacher needs to go through to allow it to precede with effectiveness. If the teacher is not concerned, then the process of applying the CT skills to the students may fail. Indirectly, the ministry's aim to include CT skills in teaching and learning activities in schools may not succeed. The stages of concern for a teacher are also closely related to 
their work quality. This statement is supported by Sultana (2015) which stated an individual's concern for an innovation directly related to their quality of work.

There are various efforts to improve our understanding on $\mathrm{CT}$, but there are challenges to overcome, particularly in applying CT skills in schools (Wientrop et al. 2015). These challenges include defining the learning progress and the curriculum involved, accessing and evaluating student progress, and preparing the teachers with sufficient skills to carry out the innovation (Grover \& Pea 2013). Thus, preparing the teachers to be able to apply CT skills in their teaching and learning is not an easy task.

$\mathrm{CT}$ is one of the $21^{\text {st }}$ century skills that should be given attention in education. According to Voogt et al. (2015), although CT is no longer new, but studies related to the application of CT skills in education are still deficient. Hence, there is an urgent need to conduct a study to examine the stage of teachers' concern towards applying CT skills in teaching and learning.

\section{METHODOLOGY}

This is a quantitative study using a survey study method, where the researchers administered a questionnaire to a sample on the attitude, opinion, behaviour and characteristics of the population (Creswell 2012). In this study, questionnaires were distributed to all the teachers in a district in Sarawak, Malaysia. Data was collected using a questionnaire adapted from the CBAM - The Stages of Concern Questionnaire (SoCQ) in Tan \& Lee's (2015) study. SoCQ is a quantitative instrument that measures the feelings of teachers or users toward an innovation (George, Hall and Stiegelbauer 2013). The questionnaire used is consists of 35 items that were measured using the Likert scale of 7 points. Respondents would mark each item on a scale of 0 - 7 based on the accuracy of the item on themselves regarding their concern towards applying CT skills in teaching and learning. There are five statements in each stage. The stages of concern are then grouped according to the seven stages of concern as suggested in the CBAM. The data of this study were analyzed based on the Measuring Implementation in Schools guide: The Stages of Concern Questionnaire by George, Hall and Stiegelbauer (2013). The following section will present the results and discussion of stages of concern based on demographic data collected.

\section{RESULTS AND DISCUSSION}

A total of 564 responds are collected in this study. 411 (72.87\%) respondents are female and 153 $(27.13 \%)$ are male. $243(43.09 \%)$ respondents are aged between 30 and 39 and $38(6.74 \%)$ respondents are age $20-29.460(81.56 \%)$ respondents are graduate and $30(5.32 \%)$ are post graduate. 189 (33.51\%) of the respondents are with 11 to 20 years of teaching experience and 35 (6.21\%) are with 31 years and above of teaching experience. 280 (49.65\%) of the respondents never attend any CT skills course or training. Detailed demographic background of the respondents are divided into gender, age, academic qualifications, teaching experience and number of times attending CT skills course or training as in Table 1. 
INTERNATIONAL JOURNAL OF ACADEMIC RESEARCH IN BUSINESS AND SOCIAL SCIENCES Vol. 9, No. 1, Jan, 2019, E-ISSN: 2222-6990 @ 2019 HRMARS

Table 1

Demographic Background of Respondents

\begin{tabular}{llcc}
\hline \multirow{2}{*}{ Variables } & Demography & $\begin{array}{c}\text { Frequency } \\
\mathrm{N}=564\end{array}$ & Percentage (\%) \\
\hline \multirow{2}{*}{ Gender } & Male & 153 & 27.13 \\
& Female & 411 & 72.87 \\
\hline \multirow{3}{*}{ Age (years old) } & $20-29$ & 38 & 6.74 \\
& $30-39$ & 243 & 43.09 \\
& $40-49$ & 198 & 35.11 \\
& 50 and above & 85 & 15.07 \\
Academic qualification & Non Graduate & 74 & 13.12 \\
& Graduate & 460 & 81.56 \\
& Post Graduate & 30 & 5.32 \\
\hline \multirow{3}{*}{ Teaching experience (years) } & $1-10$ & 184 & 32.62 \\
& $11-20$ & 189 & 33.51 \\
& $21-30$ & 156 & 27.66 \\
& 31 and above & 35 & 6.21 \\
\hline \multirow{3}{*}{ Number of times attending CT } & 1 time & 280 & 49.65 \\
skills course or training & 2 times & 125 & 22.16 \\
& 3 times and & 51 & 9.04 \\
& above & 108 & 19.15 \\
\hline
\end{tabular}

1) Stages of Concern toward Application of Computational Thinking Skills in Teaching and Learning Based on Age Group

The stages of concern for all age groups show the highest score at Stage 0 (Unconcerned). According to George, Hall \& Stiegelbauer (2013), the high score of Stage 0 shows that respondents are not only concerned about the application of CT skills in teaching and learning, but there are other tasks and activities they pay attention to. The findings also show the second highest score for each age group is at Stage 3 (Management). The second highest percentage score in Stage 3 shows that the respondents are concerned about time or other management of the innovation. In other words, respondents are concerned about the aspects of management and the time to be taken for this innovation (George, Hall \& Stiegelbauer 2013). The score for the group 20 -29, $40-$ 49 and 50 and above show the Stage 1 score higher than the Stage 2 score. This shows that teachers in these groups are likely to have positive and proactive perspective and are slightly worried about the impact of this innovation on their personal. This is a "positive one-two split". It also shows that teachers in these groups are open and interested in learning more about the application of CT skills in teaching and learning. Stage 4 (Consequence) shows the lowest score for each age group as shown in Figure 1. Low intensity at Stage 4 shows that respondents are less 
INTERNATIONAL JOURNAL OF ACADEMIC RESEARCH IN BUSINESS AND SOCIAL SCIENCES

Vol. 9, No. 1, Jan, 2019, E-ISSN: 2222-6990 @ 2019 HRMARS

concerned about the effect of the application of CT skills in teaching and learning to their students. The percentage score based on age groups are shown in Table 2 as follows.

Figure 1

Teachers' Stages of Concern toward Application of Computational Thinking Skills Based on Age Group

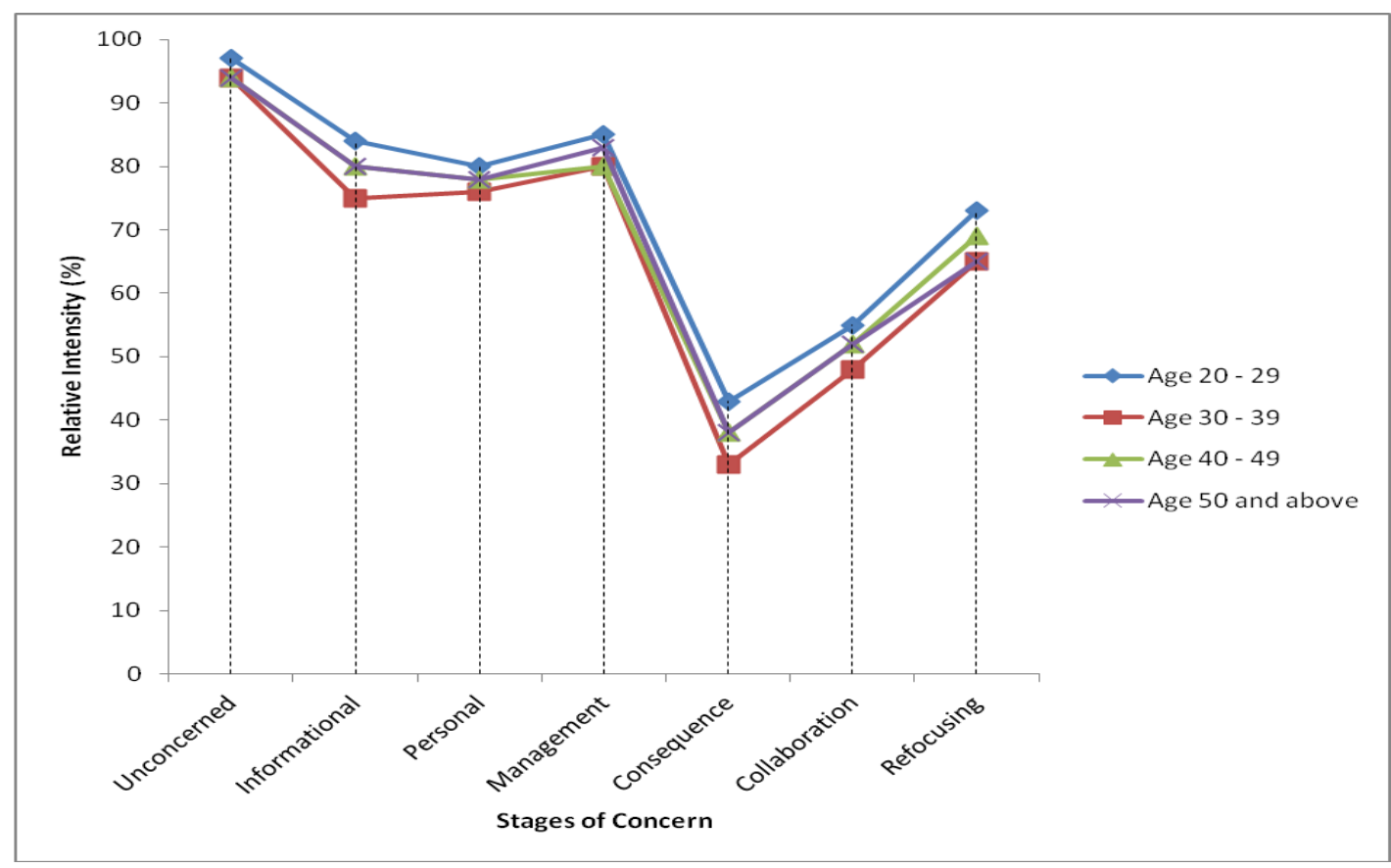

Table 2

Stages of Concern Percentage Score Based on Age Group

\begin{tabular}{lccccccc}
\hline \multicolumn{1}{c}{ Age Group } & Stage 0 & Stage 1 & Stage 2 & Stage 3 & Stage 4 & Stage 5 & Stage 6 \\
\hline Age 20 - 29 & 97 & 84 & 80 & 85 & 43 & 55 & 73 \\
Age 30 - 39 & 94 & 75 & 76 & 80 & 33 & 48 & 65 \\
Age 40 - 49 & 94 & 80 & 78 & 80 & 38 & 52 & 69 \\
Age 50 and above & 94 & 80 & 78 & 83 & 38 & 52 & 65 \\
\hline
\end{tabular}

2) Stages of Concern toward Application of Computational Thinking Skills in Teaching and Learning Based on Academic Qualification Group

The stages of concern for all academic qualification groups showed the highest score at Stage 0 (Unconcerned). The higher the Stage 0 score indicated other things, innovations or activities are of greater concern that the innovation under consideration (George, Hall \& Stiegelbauer 2013). 
INTERNATIONAL JOURNAL OF ACADEMIC RESEARCH IN BUSINESS AND SOCIAL SCIENCES Vol. 9, No. 1, Jan, 2019, E-ISSN: 2222-6990 @ 2019 HRMARS

Second highest score for all groups score at Stage 3 (Management) indicates the respondents have intense Management concerns but also have strong ideas about how the change process should be different. The findings show that the Stage 2 score is higher than Stage 1 score for NonGraduate group as in Figure 2. This is a "negative one-two split". This shows that respondents are with various degrees of doubt and potential resistance to an innovation. The teachers in this group are more concerns about an innovation's effect on personal position rather than the desire to learn more about the innovation. A teacher with this score probably will not be able to consider a proposed innovation objectively until their personal Stage 2 concerns are reduced. The lowest score for all academic qualification groups are at Stage 4 which indicates all respondents are less concerned about the consequence of application of CT skills toward their students. The percentage score based on academic qualification groups are shown in Table 3.

Figure 2

Teachers' Stages of Concern toward Application of Computational Thinking Skills Based on Academic Qualification Group

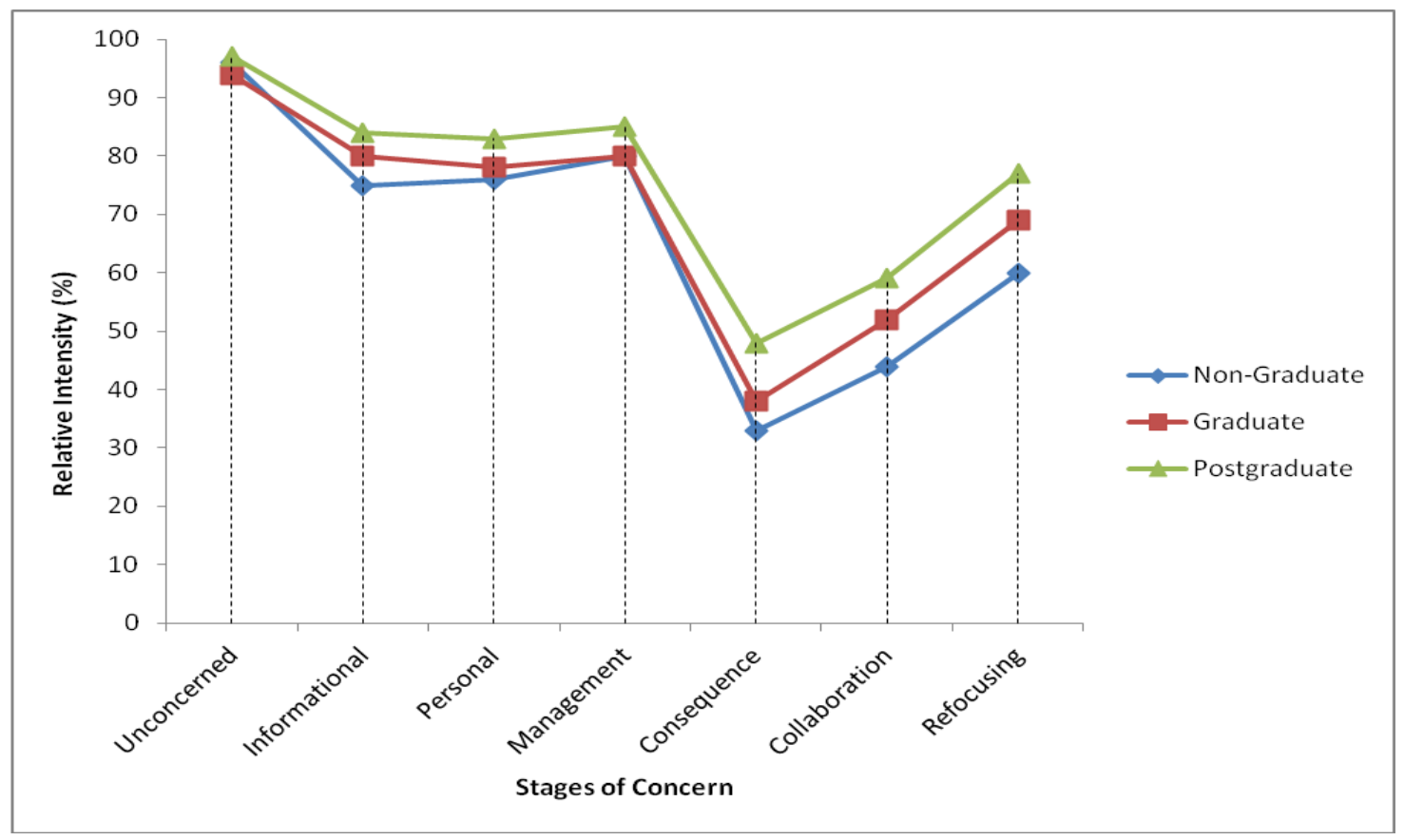

Table 3

Stages of Concern Percentage Score Based on Academic Qualification Group

\begin{tabular}{lccccccc}
\hline Academic Qualification Group & Stage 0 & Stage 1 & Stage 2 & Stage 3 & Stage 4 & Stage 5 & Stage 6 \\
\hline Non-Graduate & 96 & 75 & 76 & 80 & 33 & 44 & 60 \\
Graduate & 94 & 80 & 78 & 80 & 38 & 52 & 69 \\
Postgraduate & 97 & 84 & 83 & 85 & 48 & 59 & 77 \\
\hline
\end{tabular}


INTERNATIONAL JOURNAL OF ACADEMIC RESEARCH IN BUSINESS AND SOCIAL SCIENCES

Vol. 9, No. 1, Jan, 2019, E-ISSN: 2222-6990 @ 2019 HRMARS

3) Stages of Concern toward Application of Computational Thinking Skills in Teaching and Learning Based on Teaching Experience Group

The stage of concern for $1-10$ years teaching experience group score the highest among all groups at Stage 0 (Unconcerned). A high Stage 0 indicates the respondents are not concerned about the innovation. The findings show the second highest for group 1-10,11-20 and 31 years and above teaching experience are at Stage 3 (Management). The high Stage 3 indicates their concerns about logistics, time, and management. These three groups also show the "negative one-two split" which depicts the respondents in these groups probably more negative toward the application of CT skills in teaching and learning and generally are not open to information about the innovation. In contrast, the second highest for group $21-30$ years of teaching experience is at Stage 1 (Informational). This indicates the respondents in this group want more information about the innovation. In addition, this group also show the "positive one-two split" where the score of Stage 1 (Informational) is higher than Stage 2 (Personal) as in Figure 3. This also indicates that respondents in this group are interested and need more information about the innovation (George, Hall \& Stiegelbauer 2013). The tailing-up of Stage 6 (Refocusing) for all groups signify the respondents have the ideas that he or she sees as having more other important things than the innovation. In addition, the tailing-up of the Stage 6 concerns could be a warning that the respondents might be resistant to the innovation. The percentage score based on teaching experience groups are shown in Table 4.

Figure 3

Teachers' Stages of Concern toward Application of Computational Thinking Skills Based on Teaching Experience Group

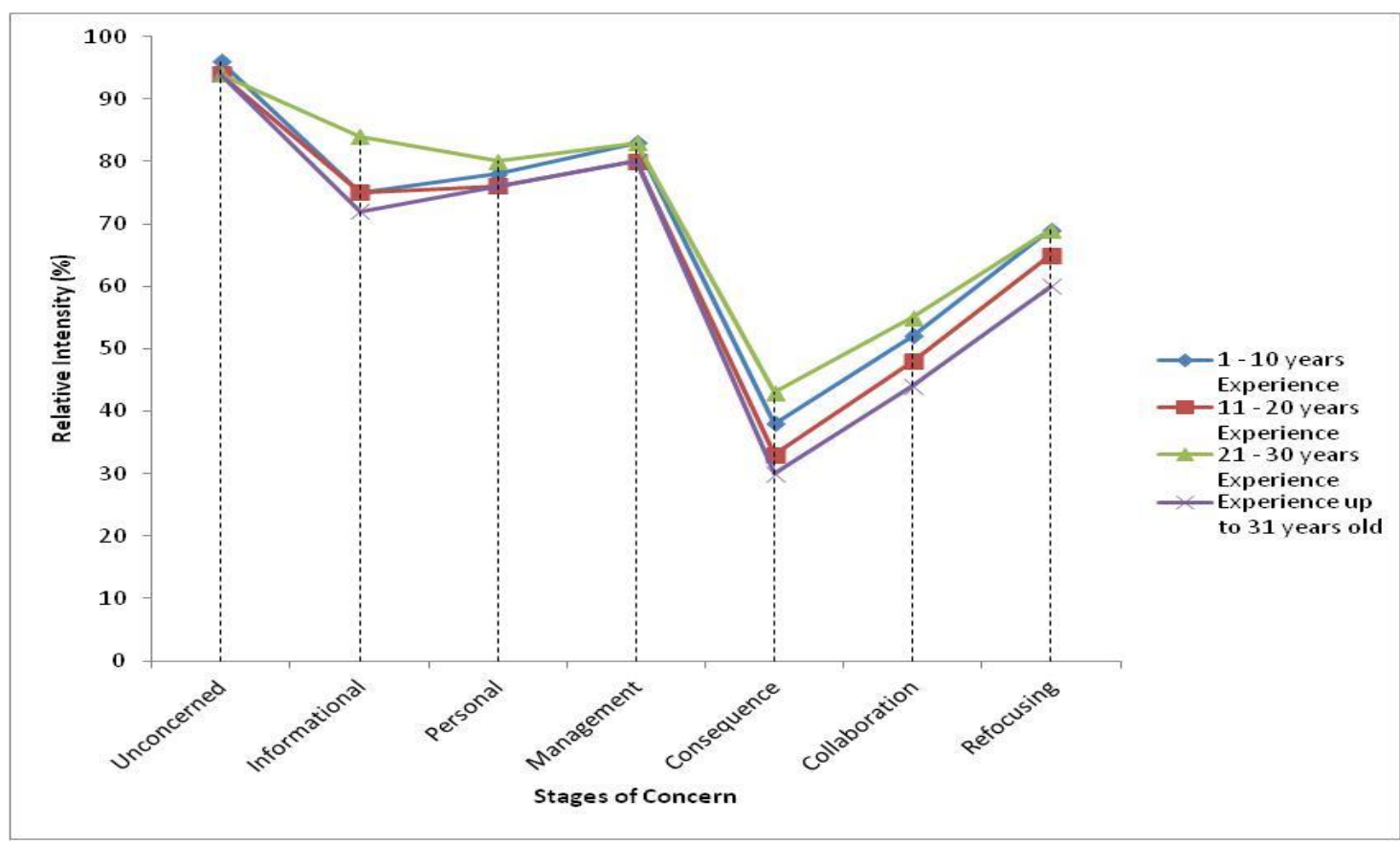


INTERNATIONAL JOURNAL OF ACADEMIC RESEARCH IN BUSINESS AND SOCIAL SCIENCES Vol. 9, No. 1, Jan, 2019, E-ISSN: 2222-6990 @ 2019 HRMARS

Table 4

Stages of Concern Percentage Score Based on Teaching Experience Group

\begin{tabular}{lccccccc}
\hline Teaching Experience Group & Stage 0 & Stage 1 & Stage 2 & Stage 3 & Stage 4 & Stage 5 & Stage 6 \\
\hline 1 - 10 years Experience & 96 & 75 & 78 & 83 & 38 & 52 & 69 \\
11 - 20 years Experience & 94 & 75 & 76 & 80 & 33 & 48 & 65 \\
21 - 30 years Experience & 94 & 84 & 80 & 83 & 43 & 55 & 69 \\
Experience up to 31 years & 94 & 72 & 76 & 80 & 30 & 44 & 60 \\
\hline
\end{tabular}

4) Stages of Concern toward Application of Computational Thinking Skills in Teaching and Learning Based on Number of Times Attending CT Skills Course or Training Group

The stages of concern for all number of times attending CT skills course or training groups show the lowest score at Stage 4 (Consequence). This suggests that the respondents have minimal concerns about the effects of the innovation on students. The percentage score of Stage 1 (Informational) is higher than Stage 2 (Personal) for the respondents who attend CT skills course or training 2 times and 3 times and above. That is a "positive one-two split". This shows that the respondents in these two groups are open to and interested in learning more about the innovation (George, Hall \& Stiegelbauer 2013). The teachers in these groups probably have a positive and proactive perspective toward the application of CT skills in teaching and learning. In contrast, the never attend and only 1 time attend groups score the same percentage for both their Stage 1 and Stage 2. The stages of concern for all groups score the highest at Stage 0 (Unconcerned) as in Figure 4. Stage 0 scores indicate the degree of interest in the innovation. The findings show the second highest for all groups are at Stage 3 (Management). The high Stage 3 indicates a high level of concern about time, logistics, or other managerial problems related to the innovation. The percentage score based on number of times attending CT skills course or training groups are shown in Table 5. 
INTERNATIONAL JOURNAL OF ACADEMIC RESEARCH IN BUSINESS AND SOCIAL SCIENCES

Vol. 9, No. 1, Jan, 2019, E-ISSN: 2222-6990 (C) 2019 HRMARS

Figure 4

Teachers'Stages of Concern toward Application of Computational Thinking Skills Based on Number of Times Attending CT Skills Course or Training Group

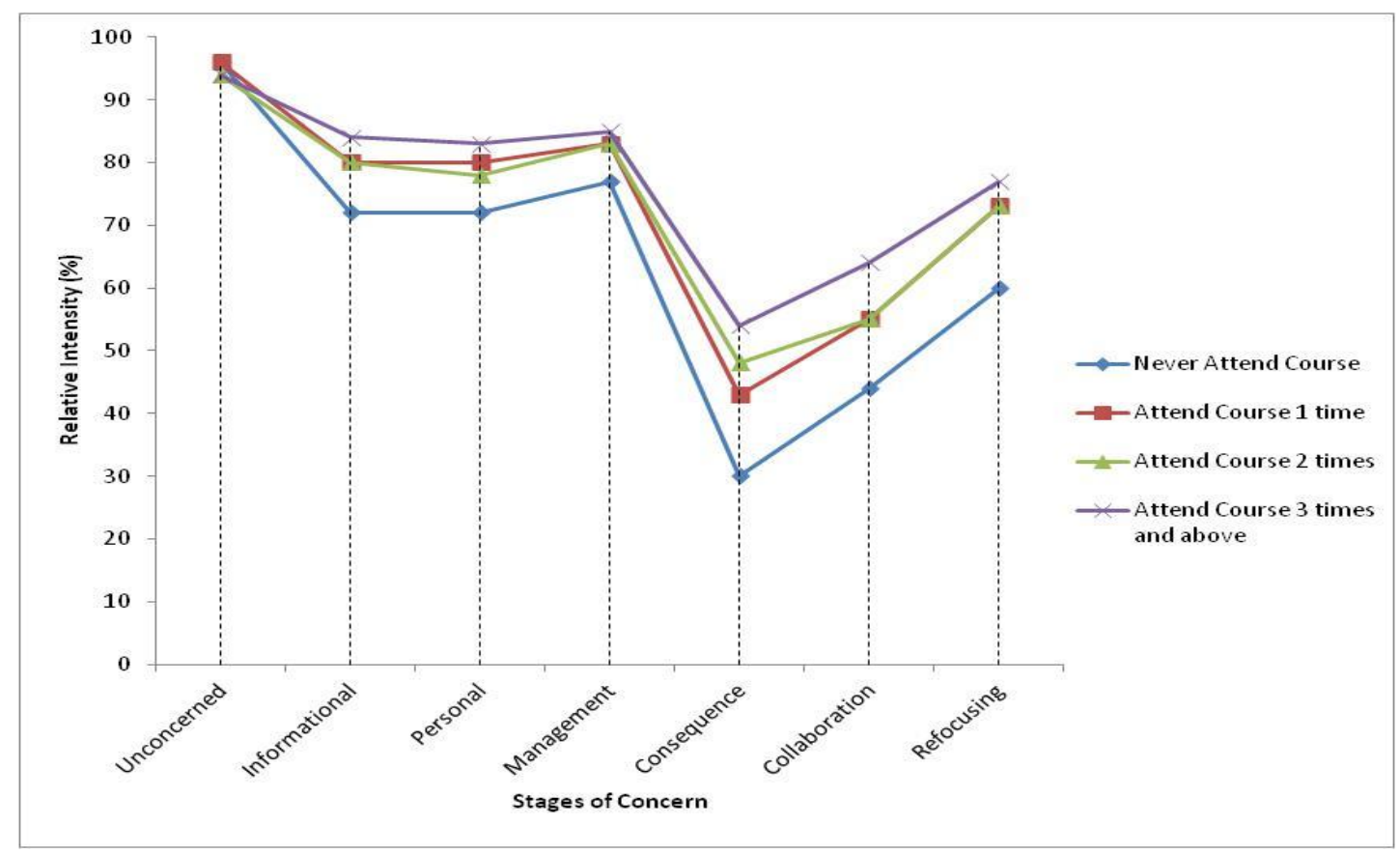

Table 5

Stages of Concern Percentage Score Based on Number of Times Attending CT Skills Course or Training Group

\begin{tabular}{lcccccccc}
\hline \multicolumn{1}{c}{$\begin{array}{c}\text { Number of Times Attending CT Skills } \\
\quad \text { Course or Training Group }\end{array}$} & Stage & Stage & Stage & Stage & Stage & Stage & Stage \\
Course & 0 & 1 & 2 & 3 & 4 & 5 & 6 \\
\hline Never Attend Course & 96 & 72 & 72 & 77 & 30 & 44 & 60 \\
Attend Course 1 time & 96 & 80 & 80 & 83 & 43 & 55 & 73 \\
Attend Course 2 times & 94 & 80 & 78 & 83 & 48 & 55 & 73 \\
Attend Course 3 times and above & 94 & 84 & 83 & 85 & 54 & 64 & 77 \\
\hline
\end{tabular}

5) Teachers' Stages of Concern toward Application of Computational Thinking Skills in Teaching and Learning in General

The stage of concern toward application of computational thinking skills in teaching and learning in general score the highest at Stage 0 (Unconcerned). The highest point indicates the most intense concern of the respondents (George, Hall \& Stiegelbauer 2013). As we assume the respondents would interpret these items in the same way as nonusers, Stage 0 score could signifies the degree of priority the respondents are placing on innovation and the relative intensity of concern about the innovation. A high Stage 0 indicates that there are a number of 
other initiatives, tasks, and activities that are of concern to the respondents. Although the score are highest at Stage 0 , the relative position of Stages 1 (Informational) and Stage 2 (Personal) are more important to understand the characteristic in the respondents. The percentage score of Stage 1 is higher than Stage 2 and depict a "positive one-two split". This suggests that the respondents are interested and need further information about the innovation. Second highest score are at Stage 1 (Informational) and Stage 3 (Management). A high score at Stage 3 indicates concerns about logistics, time and management related to the innovation. Meanwhile, the lowest score for all the respondents in general scores at Stage 4 (Consequence) as in Figure 5. A low Stage 4 and Stage 5 (Collaboration) scores suggest that the respondents have minimal concerns about the effect of application of CT skills on their student and they are not concerned about working with others. The Stage 6 (Refocusing) tailing-up suggest the respondents have strong ideas about how to do things differently. These ideas may be positive, but it could be a warning that the respondent might be resistant to the innovation. A concise display of the distribution of peak stage scores are as in Table 6.

Figure 5

Teachers' Stages of Concern toward Application of Computational Thinking Skills in Teaching and Learning in General

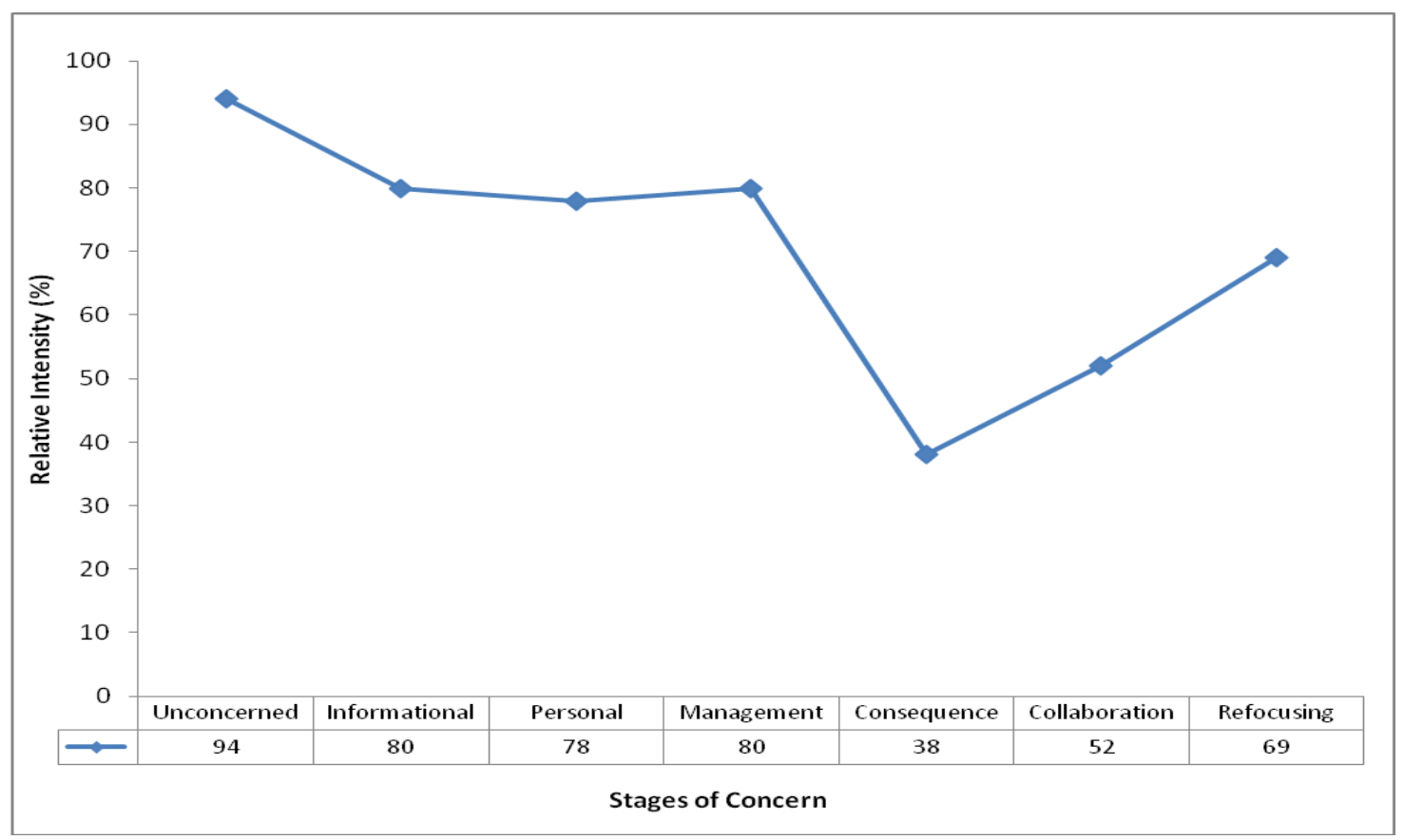


INTERNATIONAL JOURNAL OF ACADEMIC RESEARCH IN BUSINESS AND SOCIAL SCIENCES Vol. 9, No. 1, Jan, 2019, E-ISSN: 2222-6990 @ 2019 HRMARS

Table 6

Frequency of Highest Concerns Stage for Individuals

\begin{tabular}{ccc}
\hline Stages of Concern & Number of Teachers & Percent of Teachers (\%) \\
\hline Stage 0 & 409 & 72.52 \\
Stage 1 & 67 & 11.88 \\
Stage 2 & 27 & 4.79 \\
Stage 3 & 45 & 7.98 \\
Stage 4 & 2 & 0.35 \\
Stage 5 & 2 & 0.35 \\
Stage 6 & 12 & 2.13 \\
\hline TOTAL & 564 & 100.00 \\
\hline
\end{tabular}

\section{CONCLUSION}

In this study, the findings have shown that the respondents were at the Unconcerned Stage followed by Informational and Management Stage. This indicated that the respondents showed minimal concern but are interested and need more information on how to apply CT skills in their teaching and learning. CT is considered a common proficiency, which should be added to each child's logical capability as an essential element of their school education (Voogt et al. 2015). As shown in this study however, there is still a lot of work to be done to make sure CT skills are applied in schools. The findings of this study are expected to assist the concern and the ministry to improve the delivery of information concerning CT skills in teaching and learning to the teachers. Future studies could be done in examining difference level of use in primary and secondary school.

\section{REFERENCES}

Angeli, C., Voogt, J., Fluck, A., Webb, M., Cox, M., Malyn-Smith, J., \& Zagami, J. (2016). A K-6 computational thinking curriculum framework: implications for teacher knowledge. Educational Technology \& Society 19(3):47-57.

Bocconi, S., Chioccariello, A., Dettori, G., Ferrari, A., Engelhardt, K. (2016). Developing computational thinking in compulsory education - Implications for policy and practice; EUR 28295 EN; doi:10.2792/792158

Creswell, J.W. (2012). Educational Research. Edisi ke-4. Boston: Pearson Education, Inc.

George, A. A., Hall, G. E., \& Stiegelbauer, S. M. (2013). Measuring implementation in schools: The Stages of Concern Questionnaire (2nd ed.). Austin, TX: Southwest Educational Development Laboratory.

Grover, S. \& Pea, R. (2013). Computational thinking in K-12: a review of the state of the field. Educ $\operatorname{Res} 42(1): 38-43$. 
INTERNATIONAL JOURNAL OF ACADEMIC RESEARCH IN BUSINESS AND SOCIAL SCIENCES

Vol. 9, No. 1, Jan, 2019, E-ISSN: 2222-6990 @ 2019 HRMARS

Hall, G. E., Wallace, R. C., \& Dossett, W. F. (1973). A Developmental Conceptualization of the Adoption Process Within Educational Institutions. Austin: Research and Development Center for Teacher Education.

Holloway, K. (2003). A Measure of Concern. DIm. Holloway, K. (pnyt.). Tools For Schools. hlm. 1-8. Ohio: National Staff Development Council.

Israel, M., Pearson, J. N., Tapia, T., Wherfel, Q. M. \& Reese, G. (2014). Supporting all learners in schoolwide computational thinking: a cross-case qualitative analysis. Computers \& Education 82:263279.

Loucks, S. F. (1983). The Concerns-Based Adoption Model (CBAM): Series Paper (Number 2). North Carolina: Technical Assistance Development System (TADS).

Matar, N. (2015). Evaluating e-learning system use by CBAM-stages of concern methodology in Jordanian universities. World of Computer Science and Information Technology Journal 5(5):7581.

Ministry of Education Malaysia. (2016). Panduan Pelaksanaan Modul Teknologi Maklumat dan Komunikasi. Putrajaya: Bahagian Pembangunan Kurikulum.

Ministry of Education Malaysia. (2017). Kempen Hour of Code. Putrajaya: Bahagian Teknologi Pendidikan.

Ministry of Education Malaysia. (2018). Kempen Hour of Code. Putrajaya: Bahagian Teknologi Pendidikan.

Mohaghegh, M. \& McCauley, M. (2016). Computational thinking: the skill set of $21^{\text {st }}$ century. International Journal of Computer Science and Information Technologies 7(3):1524-1530.

Roselita Ali@Yusof, Jamaludin Badusah, Aliza Alias \& Roshdi Said. (2017). Keprihatinan guru terhadap pendekatan belajar melalui bermain dalam pengajaran bahasa Malaysia berdasarkan model penerimaan berasaskan keprihatinan. Journal of Advanced Research in Social and Behavioural Sciences 6(1):31-40.

Sharifah Nor Puteh, Nor Adibah Ghazali, Mohd Mahzan Tamyis \& Aliza Ali. (2012). Keprihatinan guru Bahasa Melayu dalam melaksanakan kemahiran berfikir secara kritis dan kreatif. Jurnal Pendidikan Bahasa Melayu 2(2):19-31.

Sultana, N. (2015). Application of Concern Based Adoption Model (CBAM) for launching the information technology based teacher education programme at AIOU. Asian Journal of Social Sciences \& Humanities 4(3):153-166.

Tan, Y. L. \& Lee, L. W. (2015). Profil tahap keprihatinan guru terhadap inovasi Kurikulum Standard Sekolah Rendah (KSSR) berdasarkan model Concern-Based Adoption Model (CBAM). Jurnal Kurikulum \& Pengajaran Asia Pasifik 3(3):1-21.

Voogt, J., Fisser, P., Good, J., Mishra, P. \& Yadav, A. (2015). Computational thinking in compulsory education: towards an agenda for research and practice. Educ Inf Technol 20:715-728.

Wang, W. (2014). Teachers' stages of concern and levels of use of a curriculum inovation in China: a case study. International Journal of English Language Teaching 1(1):22-31.

Wientrop, D., Beheshti, E., Horn, M., Orton, K., Jona, K., Trouille, L., \& Wilensky, U. (2015). Defining computational thinking for mathematics and science classrooms. J Sci Educ Technol 25(1):127147. 
INTERNATIONAL JOURNAL OF ACADEMIC RESEARCH IN BUSINESS AND SOCIAL SCIENCES

Vol. 9, No. 1, Jan, 2019, E-ISSN: 2222-6990 @ 2019 HRMARS

Wing, J. M. (2017). Computational thinking's influence on research and education for all. Italian Journal of Educational Technology, 25(2), 7-14. doi: 10.17471/2499-4324/922.

Yadav, A., Mayfield, C., Zhou, N., Hambrusch, S., \& Korb, J. T. (2014). Computational thinking in elementary and secondary school teacher education. ACM Trans. Comput. Educ. 14(1). 